\title{
Use of mammals in a semi-arid region of Brazil: an approach to the use value and data analysis for conservation
}

\author{
Suellen da Silva Santos ${ }^{1,2,3^{*}}$, Reinaldo Farias Paiva de Lucena ${ }^{4} \mathbb{B}$, Hyago Keslley de Lucena Soares ${ }^{1,2,3}$, \\ Vanessa Moura dos Santos Soares ${ }^{1,2}$, Natalice Santos Sales ${ }^{2,5}$ and Lívia Emanuelle Tavares Mendonça $a^{1,2,6}$
}

\begin{abstract}
Background: This study aimed to survey the knowledge and use of mammals by the residents of the rural community of Capivara in the municipality of Solânea (Paraíba State, Northeast Brazil) and to propose a new method of using the use value as a tool for data analysis in ethnozoological surveys.

Methods: The uses attributed to mammals were recorded through semi-structured interviews conducted with the breadwinners (men and women) living in the community. The species were identified through guided tours, by descriptions made by the interviewees, and using specimens donated by them, as well as by comparison with the pertinent scientific literature (morphological and ecological). Through the use value differentiated analysis, it was possible to distinguish the current use value of the species (effective use) from their potential use value (knowledge, but no effective use) to determine their real importance related to the uses cited by the studied group.
\end{abstract}

Results: Nineteen species were cited; however, only 17 of them were identified and then distributed in 13 families. The other species were identified at the genus level Leopardus sp. and order Rodentia. The species were classified into 6 categories of use: food, captive breeding, zootherapeutic, artisanal, magic/religious, and veterinary purposes.

Conclusions: This article discusses possible conservation solutions, given the irregular exploitation of some species, warning about the biodiversity, and traditional knowledge conservation.

Keywords: Animal use, Ethnomastozoology, Use value, Current use value

\section{Background}

The biological diversity of mammals in Brazil, described by Paglia et al. [1], comprises 701 species distributed in 243 genera, 50 families, and 12 orders. In the semi-arid region, Albuquerque et al. [2] recorded 156 species occurring in the Caatinga. This biome has gotten the attention of researchers focusing on mammal studies, with some specific surveys aimed at obtaining data on the richness, ecology, ethology, physiology, distribution, and taxonomy of species (e.g., [3-9]).

Regarding the traditional use of mammals, a growing number of studies have been carried out in Brazil (e.g., [10-13]). In the Caatinga biome, some species of mammals

\footnotetext{
* Correspondence: suellen.gba@gmail.com

${ }^{1}$ Universidade Federal da Paraíba, João Pessoa, Brazil

${ }^{2}$ UEPB, Campina Grande, Brazil

Full list of author information is available at the end of the article
}

have been used for food, pets, medicinal, magic/religious, artisanal, veterinary (folk medicine used in animals), and control (slaughter of wild animals that feed on domestic species) purposes (e.g., [14-19]). Animals that have utility value for the population are mostly killed in hunting activities, which, according to Chiarello et al. [20], represent one of the greatest threats to wild mammals. Consequently, this activity has caused a significant decline in several species' populations throughout the world [21-25], intensifying the process of fauna extinction.

In order to understand the dynamics of use of the local fauna by the populations, data collection techniques have been diffused and currently used by different researchers. Among these techniques, the use value index (UV) stands out as a quantitative method, proposed by Phillips and Gentry [26, 27], in ethnobotanical studies, and adapted by Rossato et al. [28]. This method makes it possible to test

(c) The Author(s). 2019 Open Access This article is distributed under the terms of the Creative Commons Attribution 4.0 International License (http://creativecommons.org/licenses/by/4.0/), which permits unrestricted use, distribution, and 
hypotheses in ethnobiological research, measuring the importance of each species at the local and regional level, according to the interviewees.

The UV is used in several ethnobotanical studies (e.g., [29-32]) and, currently, also in ethnozoological research (e.g., [33-36]) to analyze the relative importance of a given species. However, because it does not distinguish current use (effective use) from potential use (knowledge, but no effective use), this index has limitations, evidenced in some ethnobotanical studies [29-31,37]. According to La Torre-Cuadros and Islebe [29], a plant, for example, can receive many citations of use without being currently used in the analyzed population. Stagegaard et al. [38] also show that the UV is fragile since it assesses a high number of potential uses, considering that the species under this perspective have no effective use.

Therefore, Lucena et al. [39] proposed, in their studies in the Brazilian semi-arid region, a change in this index and developed the current use value ( $\left.\mathrm{UV}_{\text {current }}\right)$, based on the uses that people reported as effective (currently executed by them), the potential use value ( $\left.\mathrm{UV}_{\text {potential }}\right)$, based on the uses that people stated to know, but are not currently executed by them, and the general use value $\left(\mathrm{UV}_{\text {gen- }}\right.$ eral), commonly used in the literature and does not distinguish between effective use and knowledge.

Currently, many studies involving local populations $[10,40-43]$ have shown that mammals are the main sources of protein in the tropical regions of the world, and this is the main factor that promotes the capture and slaughter of these animals. Thus, the preference of human populations for large- and medium-sized species was also analyzed based on the Optimal Foraging Theory, which is a model of evolutionary ecology that has been used in the analysis of subsistence of human populations in several studies $[44,45]$. This theory predicts that the animal will try to maximize the amount of resource obtained (benefit) per unit of time spent on foraging (cost) [46, 47].

However, some studies [40, 48-50] have shown that when there is a lack of preferred species, hunters have to capture a higher number of prey of less appreciated species, as well as to increase the invested time and cover a larger area to capture the animals. It is noteworthy that several cultural factors (taboos involving the choice of species and/or hunting areas, and forms of use) are involved in the selection, capture, and use of species by local populations and have considerable impacts on the populations of the species used $[41-43,48,51]$. In this sense, the understanding of these factors is essential to subsidize actions aimed at the management and conservation of the animals used [41, 43, 52].

Thereby, this study recorded and evaluated how wild mammals are used by residents of a rural community in a semi-arid region of northeastern Brazil. It was assumed that the biomass is a determinant factor in the choice and use of wild mammals by traditional/local populations. Thus, the following hypotheses were tested: (1) The higher the biomass of a species, the higher its use value and (2) the calculation of the differentiated use value modifies the list of the locally most important species.

\section{Materials and methods}

\section{Study area}

This study was carried out in the rural community of Capivara, municipality of Solânea (latitude $06^{\circ} 45^{\prime} 18^{\prime \prime} \mathrm{S}$ longitude $\left.35^{\circ} 32^{\prime} 24^{\prime \prime} \mathrm{W}\right)$, inserted in the geoenvironmental unit of the "Borborema" Plateau, located in the "Agreste" Mesoregion and in the Solânea Microregion, in the semi-arid region of Paraíba State, Northeast Brazil, at $99.3 \mathrm{~km}$ from João Pessoa, the state capital, and can be accessed via Highways BR 230/BR 041/PB 105 [53] (Fig. 1). This municipality has a population of 26,925 inhabitants distributed in an area of $232,096 \mathrm{~km}^{2}$; 7361 of them live in rural areas (3699 women and 3662 men), and about 17,273 are literate [54].

\section{Data collection}

This research was carried out in 2012, through several visits to the community for data collection and other observations. All the residences of the chosen sample were visited, but not all the family breadwinners were found, even after repeated visits to their residences. Therefore, 108 informants were interviewed ( 52 men and 56 women).

Information on the use of mammals in the region was obtained through semi-structured questionnaires, complemented by free interviews and informal conversations [55]. The participants' socioeconomic data were also recorded during the interviews (Table 1).

Before each interview, the participants were explained about the aims of the study and then were asked to sign the informed consent form, which is required by the National Health Council through the Ethics Research Committee (Resolution 466/12) and approved by the State University of Paraíba (protocol No. 45051115.5.0000.5187). The interviews dealt both with the population's socioeconomic status and information on the mammals in the region such as the purposes for which they are used, their respective parts used, animal capture techniques, and morphological and ecological descriptions of the species.

In an attempt to obtain reliable answers from the interviewees, a friendly dialogue was held at the first contact with the participants, dealing with topics such as the pleasure of contact with nature, the taste of wild animal meat, and the experience transmitted through generations. As the informal conversation was held in a relaxed manner, the questions from the semi-structured questionnaire were asked. In addition, there was more 


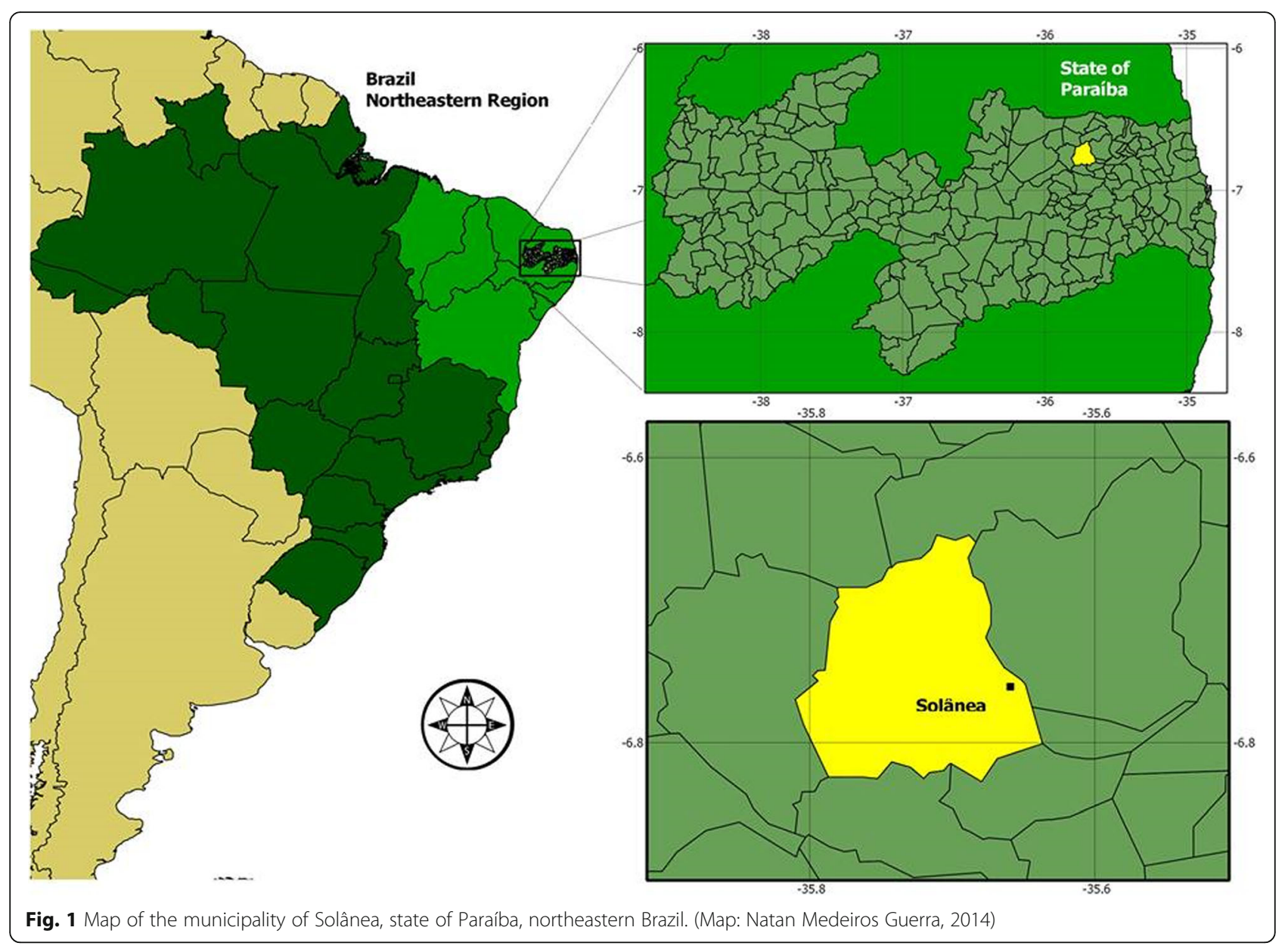

than one contact with the residents to strengthen the bonds of trust between researcher and informant.

Guided tours were conducted during the informants' daily activities and non-participant observation was carried out [56] for a more precise recording of the animal capture techniques, the preference for species, and other relevant information.

To mitigate the possible effects of the non-recording or non-veracity of information, the synchronous confirmation of the information was made, checking the data obtained from one informant with those obtained from others.

The species vernacular names were recorded exactly as mentioned by the interviewees, and the species were identified as follows: (1) analysis of the specimens or their parts donated by the informants, (2) analysis of animals pictures taken during the interviews and during the monitoring of hunting activities, (3) based on vernacular names, with the help from taxonomists who knew the fauna of the study (researchers from the Federal University of Paraíba - Campus I - Mastozoology Laboratory), and (4) based on ethnozoological studies previously performed in the study mesoregion $[12,13,16,57]$.

\section{Data analysis}

The UV was applied to quantify the local importance of a species according to the interviewees [28]. In the present study, this index was calculated based on Lucena et al. [39], considering three types of data: uses that people cited as effective (known and currently applied by them) $\left(\mathrm{UV}_{\text {current }}\right)$, uses that people were aware of but do not themselves use $\left(\mathrm{UV}_{\text {potential }}\right)$, and the general use value $\left(\mathrm{UV}_{\text {general }}\right)$ referred to uses that were commonly reported in the literature but with no distinction between use and knowledge [28]. This distinction was made during interviews by asking the interviewees to indicate uses that were effective (current) or not (potential). These values were calculated using the Microsoft Excel software (2012).

$$
\mathrm{UV}_{\text {current }}=\mathrm{Ui}_{\text {current } / \mathrm{n}}
$$

where $\mathrm{UV}_{\text {current }}=$ current use value of the species, $\mathrm{Ui}=$ number of citations of current use of the 
Table 1 Socioeconomic profile of the respondents

\begin{tabular}{ll}
\hline Gender & \\
\hline Men & 52 \\
Women & 56 \\
Age group & \\
$19-30$ & 16 \\
$31-50$ & 42 \\
$51-70$ & 34 \\
$>70$ & 1 \\
Not informed & 15 \\
Residency time & \\
$>60$ years & 2 \\
$31-60$ years & 14 \\
15-30years & 51 \\
$<15$ years & 35 \\
Not informed & 6 \\
Schooling level & \\
Semi-illiterate & \\
Illiterate & 16 \\
Incomplete primary education & 34 \\
Complete primary education & 35 \\
Incomplete secondary education & 4 \\
Complete secondary education & 2 \\
Not informed & 15 \\
\hline
\end{tabular}

species mentioned by each informant, $n=$ total number of informants.

$$
\mathrm{Uv}_{\text {potential }}=\mathrm{Ui}_{\text {potential } / \mathrm{n}}
$$

where $U_{\text {potential }}=$ potential use value of the species, $\mathrm{Ui}$ $=$ number of citations of potential use of the species mentioned by each informant, $n=$ total number of informants.

$$
\mathrm{Uv}_{\text {general }}=\mathrm{Ui}_{\text {general } / \mathrm{n}}
$$

where $U_{\text {general }}=$ general use value of the species, $\mathrm{Ui}=$ number of citations of general use of the species mentioned by each informant, $n=$ total number of informants.

The counting of the animal species citations was made considering information such as preparation methods, therapeutic indications, and artisanal purposes, and for each different kind of use of the same species, an additional citation was counted.

For example, regarding food category, the citations for the use of cooked or roast meat were counted as distinct uses, i.e., cooked meat was considered one kind of use and roast meat another (a citation for each one). As for the medicinal animals, the citations were related to the specimen's parts used and to the diseases treated by their uses. Therefore, when the melted animal fat is used to treat uterine problems, bone inflammation, throat inflammation, and toothache, four different citations of use are counted. If from this same specimen, another biological part is used for other therapeutic indications, more uses are attributed to it.

With regard to the artisanal use, the citations were counted according to the specimen's biological part used (e.g., leather, carapace) and to the purposes attributed to it, such as for tambourines, zabumba, saddle, chair seat, sandal sole, seats for motorcycles, and belts, which are different items representing a citation each. This logistics is used as a model for the other categories of use, except for breeding and control since there is no diversity in their description.

The one-way ANOVA was used to identify significant differences between the results from the three types of use value calculated for each species, and the Tukey test was applied to identify which means were statistically different between each other $(p<0.05$ and $p<0.01)$. The data analysis was performed in the Past 2.17c. Furthermore, the similarity analysis (cluster) was performed to analyze the similarity between these UVs, using the PRIMER 6.0 software.

To test if the biomass of the species predicted the use value attributed to them, a simple linear regression was made, adopting the $\mathrm{UV}_{\text {current }}$ as a dependent variable and the biomass of each species as an independent variable, using the BioEstat 5.0 software.

Biomass was calculated by multiplying the number of captured animals by the medium body mass of the species, found in the literature on mammals [58-60].

\section{Results}

The interviewed residents cited 19 specimens; 17 of them were identified at the species level and distributed in 13 families, the others were identified at the genus level Leopardus sp. and order Rodentia.

Several kinds of use were attributed to the species, which were distributed in 6 categories: food (19 species), breeding (12 species), artisanal (11 species), zootherapeutic ( 9 species), magic/religious (1 species), and veterinary purposes (1 species) (Table 2 ).

It was noticed that the informants (men and women) are involved in pre- and post-hunting activities and that the men are responsible for obtaining the resources by hunting, making products used in popular veterinary and for magic/religious purposes (popular belief). The women are in charge of making food and zootherapeutic products. However, both men and women are involved in activities relating to the breeding of wild species.

Galea spixii (Wagler, 1831) (226 citations), Puma yagouaroundi (É. Geoffroy Saint-Hilaire, 1803) (190 citations) and Leopardus sp. (182 citations) had the highest number of citations. Regarding the utility value, G. spixii 
Table 2 Ordering of the ten most important local species, based on the use value (UV), in the rural community of Capivara in the municipality of Solânea (Paraíba State, northeastern Brazil)

\begin{tabular}{|c|c|c|c|c|}
\hline Scientific name & Vernacular name & $U V_{\text {general }}$ & $U V_{\text {current }}$ & $U V_{\text {potential }}$ \\
\hline \multicolumn{5}{|l|}{ Primates } \\
\hline \multicolumn{5}{|l|}{ Cebidae } \\
\hline Callithrix jacchus (Linnaeus, 1758) & Common marmoset & - & - & $10^{\circ}$ \\
\hline \multicolumn{5}{|l|}{ Carnivora } \\
\hline \multicolumn{5}{|l|}{ Canidae } \\
\hline Cerdocyon thous (Linnaeus, 1766) & Fox & $4^{\circ}$ & $9^{\circ}$ & $3^{\circ}$ \\
\hline \multicolumn{5}{|l|}{ Felidae } \\
\hline Leopardus sp. & 'Polka dot cat' / Wild cat' & $3^{\circ}$ & $8^{\circ}$ & $2^{\circ}$ \\
\hline Puma yagouaroundi (É. Geoffroy Saint-Hilaire, 1803) & Jaguarundi (Red Cat / Black Cat / Blue Cat) & $2^{\circ}$ & $9^{\circ}$ & $1^{\circ}$ \\
\hline \multicolumn{5}{|l|}{ Mephitidae } \\
\hline Conepatus semistriatus (Boddaert, 1785) & Skunk & $7^{\circ}$ & $4^{\circ}$ & $5^{\circ}$ \\
\hline \multicolumn{5}{|l|}{ Cingulata } \\
\hline \multicolumn{5}{|l|}{ Dasypodidae } \\
\hline Euphractus sexcinctus (Linnaeus, 1758) & Yellow armadillo & $7^{\circ}$ & $5^{\circ}$ & $4^{\circ}$ \\
\hline \multicolumn{5}{|l|}{ Rodentia } \\
\hline \multicolumn{5}{|l|}{ Caviidae } \\
\hline Galea spixii (Wagler, 1831) & Prea & $1^{\circ}$ & $1^{\circ}$ & $5^{\circ}$ \\
\hline Kerodon rupestris (Wied-Neuwied, 1820) & Rock cavy & $6^{\circ}$ & $3^{\circ}$ & $6^{\circ}$ \\
\hline \multicolumn{5}{|l|}{ Echimyidae } \\
\hline Thrichomys laurentius (Thomas, 1904) & Punaré rat & $5^{\circ}$ & $2^{\circ}$ & $9^{\circ}$ \\
\hline \multicolumn{5}{|l|}{ Lagomorpha } \\
\hline \multicolumn{5}{|l|}{ Leporidae } \\
\hline Sylvilagus brasiliensis (Linnaeus, 1758) & Forest rabbit & $10^{\circ}$ & $10^{\circ}$ & - \\
\hline \multicolumn{5}{|l|}{ Pilosa } \\
\hline \multicolumn{5}{|l|}{ Myrmecophagidae } \\
\hline Tamandua tetradactyla (Linnaeus, 1758) & Collared anteater & $9^{\circ}$ & $7^{\circ}$ & $8^{\circ}$ \\
\hline \multicolumn{5}{|l|}{ Didelphimorpha } \\
\hline \multicolumn{5}{|l|}{ Didelphidae } \\
\hline Didelphis albiventris Lund, 1840 & Brazilian opossum & $8^{\circ}$ & $6^{\circ}$ & $7^{\circ}$ \\
\hline
\end{tabular}

had the highest general use value $\left(\mathrm{UV}_{\text {general }}=2.09\right)$, followed by the carnivore species $P$. yagouaroundi $\left(\mathrm{UV}_{\mathrm{gen}}\right.$ eral $=1.76)$ and Leopardus sp. $\left(\mathrm{UV}_{\text {general }}=1.68\right)$. The rodents G. spixii $\left(\mathrm{UV}_{\text {current }}=1.49\right)$, Thrichomys apereoides (Lund, 1941) $\left(\mathrm{UV}_{\text {current }}=1.12\right)$, and Kerodon rupestris (Wied-Neuwied, 1820) $\left(\mathrm{UV}_{\text {current }}=0.75\right)$ had the highest current use (effective use) values. This high $\mathrm{UV}_{\text {current }}$ indicates that possibly these species have been exploited locally. P. yagouaroundi $\left(\mathrm{UV}_{\text {potential }}=1.50\right)$, Leopardus sp. $\left(\mathrm{UV}_{\text {poten- }}\right.$ tial $=1.36)$, and Cerdocyon thous (Linnaeus, 1766) $\left(\mathrm{UV}_{\text {poten- }}\right.$ tial $=1.36)$ were the most prominent species regarding the potential use value (Tables 2 and 3) (Fig. 2).

Some of the cited species are used for more than one purpose, such as $C$. Thous, which was related to 6 different kinds of use, especially in the local folk medicine, being used to treat 18 pathologies (Table 3), reflecting thus its local importance.

According to the one-way ANOVA, there was a significant difference between the three types of use value calculated for the species used $(F=4.048 ; P<0.02467)$, especially between the $\mathrm{UV}_{\text {current }}$ and the $\mathrm{UV}_{\text {general }}$ (Tukey test $P<0.05)$. This pattern is observed in the similarity analysis, in which the $\mathrm{UV}_{\text {current }}$ is included in a group different from the other two types of UV (Fig. 3).

The results from the regression analysis (Fig. 4) show that there is no significant relationship between the biomass of the consumed wild animals and the UV attributed to them (readjusted $=0.0723 ; F=0.0558 ; p=0.39$ ).

\section{Discussion}

The use of mammal species is a practice carried out all over the world [43, 61-66], demonstrating that the use of wild animals is supposed to be culturally disseminated. In the semi-arid region of Brazil, these relationships between humans and nature become even more important, because the environmental factors associated with precarious socioeconomic conditions led these 


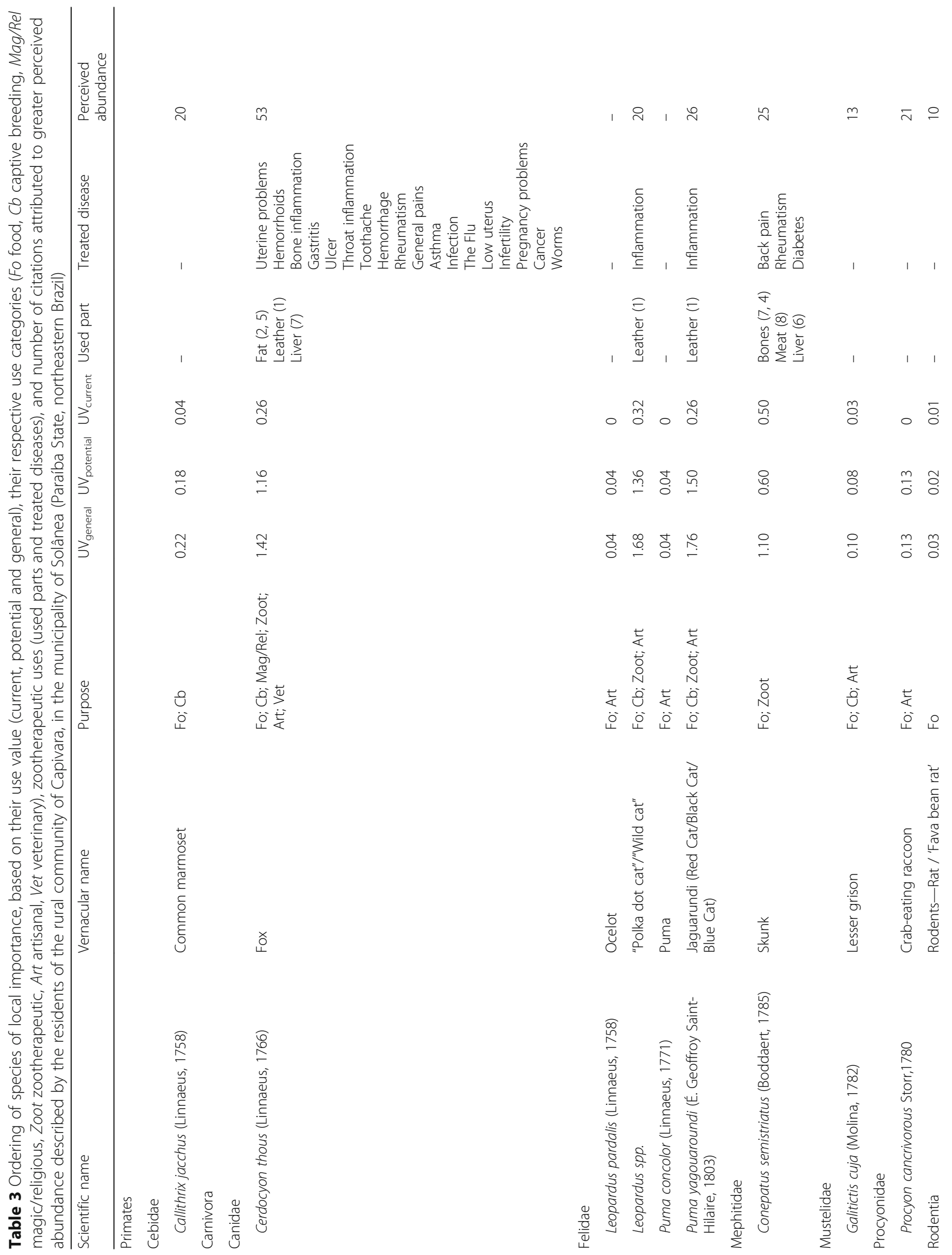




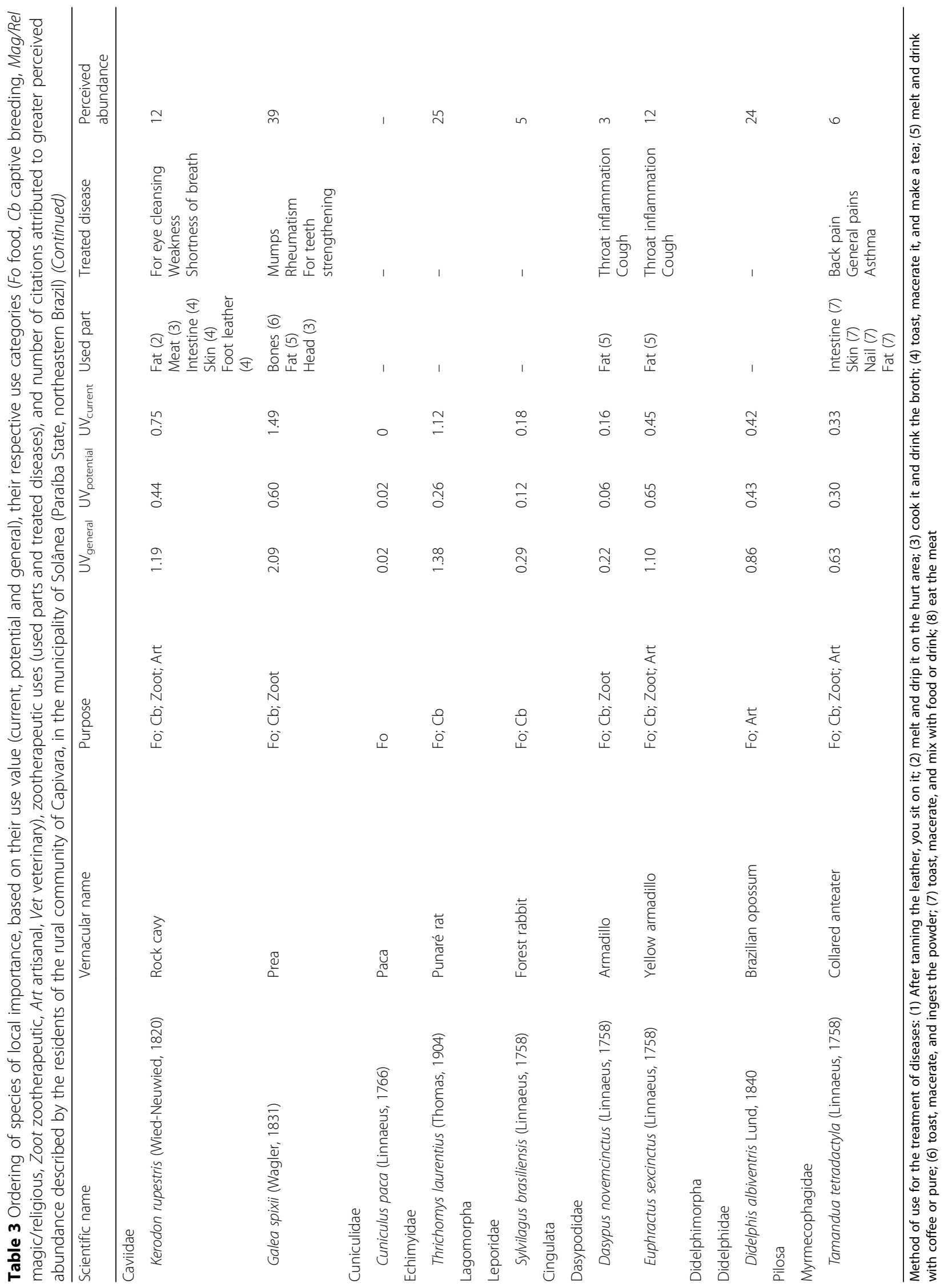




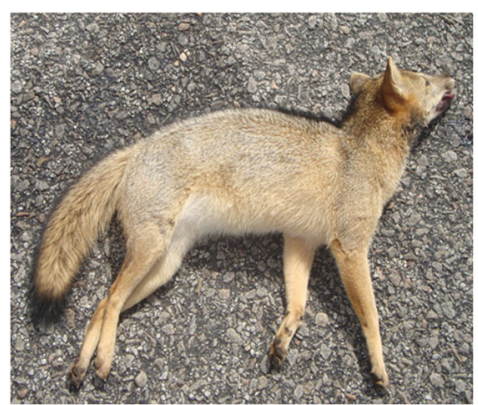

Cerdocyon thous (Smith,1839)

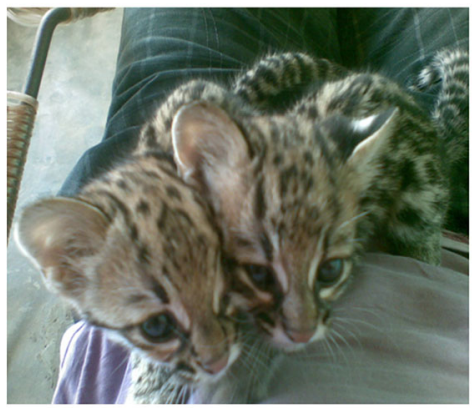

Leopardussp.

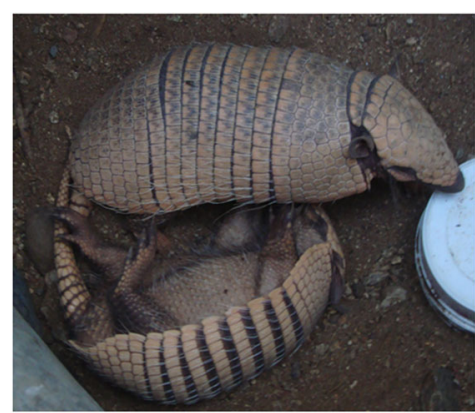

Euphractus sexcinctus Linnaeus, 1758

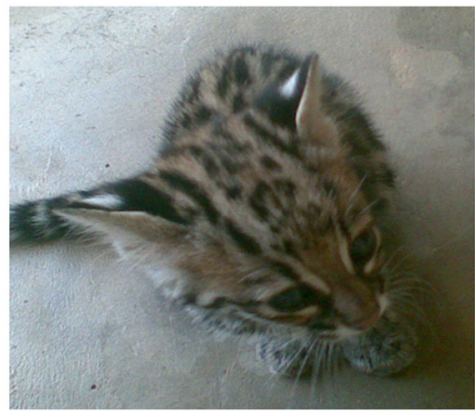

Leopardussp.

Fig. 2 Photographic records of species cited by the residents of the rural community of Capivara in the municipality of Solânea (Paraíba State, northeastern Brazil)

people to develop a very unique sociocultural structure and a strong relationship with the faunistic and floristic resources of their region. This is reported in several studies (e.g., [16, 67-71]), especially during drought periods, when the agriculture and the raising of domestic animals are not feasible due to the lack of resources [16, 42].

Lucena et al. [72] explain that men and women have different patterns of knowledge (similar or not) of the natural resources, depending on the study region. The data obtained in our study indicate that men and women know and use the same species. Concerning the mastery of the categories, men, because they are mostly in contact with nature, work outside the residences, and besides performing cinegetic activities, they are more related to these practices. However, women demonstrate mastery in preparing the animals used

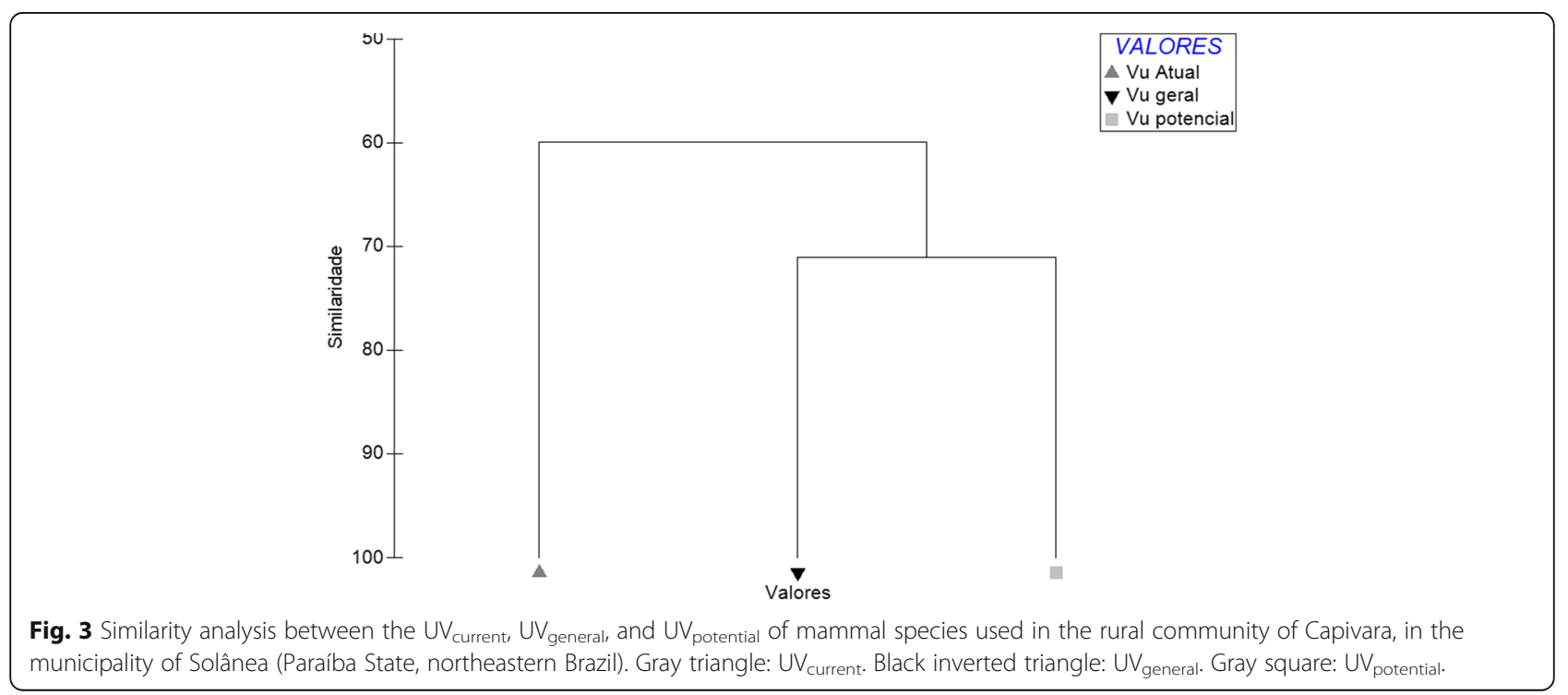




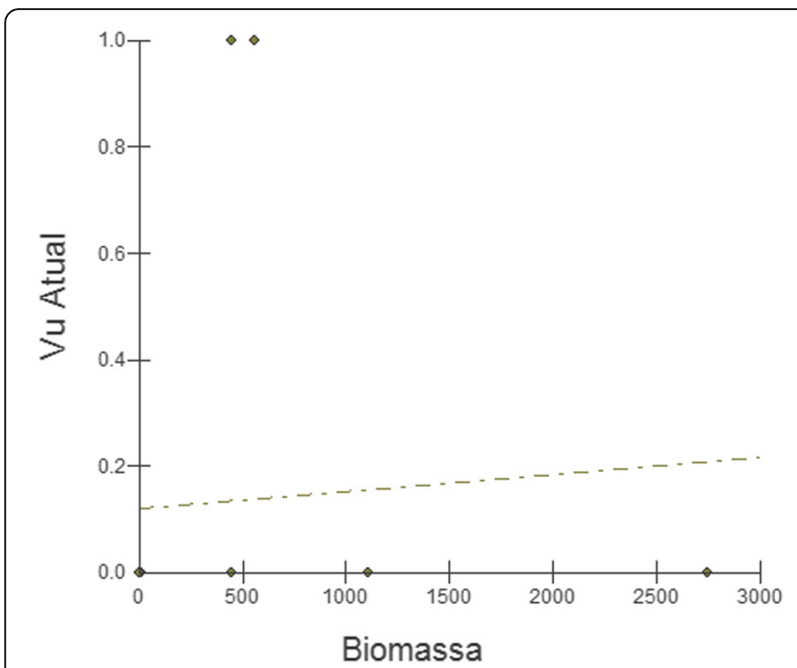

Fig. 4 Relationship between the biomass and the $U V_{\text {current }}$ of the species used in the rural community of Capivara, in the municipality of Solânea (Paraíba State, northeastern of Brazil)

in the culinary and those related to folk medicinal treatments. This can be explained by the fact that women are usually responsible for domestic activities and family welfare.

All the species described were attributed to food purpose, obtaining a higher number of citations and higher use values; these animals are important because they are much appreciated in the local cuisine. This trend of preference for some animal species as a food resource has already been observed in some studies in the world $[16,42,66,73-77]$ and also in the studied community, where the hunting is directed to animals of which meat is considered tasty.

Regarding the breeding category, some studies show that this relationship between human populations and animals is common in the semi-arid region of Brazil [12, 24, 78]. In the study area, the species are used as pets due to the affective bond and their beauty (e.g., Leopardus sp.) and because they can later be used as food resource (e.g., Euphractus sexcinctus) (Fig. 2), reflecting their number of citations. The latter one (food resource) is also reported by Alves et al. [78].

The carnivorous species had a significant number of citations for artisanal purposes, and leather was commonly cited as the material used to make musical items, such as tambourine and zabumba, as well as saddles, motorcycle seats, chair covers, car seats, shoe and boot soles, bags, hats, key rings, and belts, among others. However, none of these ornaments were seen in the visited residences. Thus, the $\mathrm{UV}_{\text {general }}$ attributed by the interviewees to the species for ornamental purposes, evidences their local importance, even though they are not currently used. Nevertheless, 11 respondents reported executing the use $\left(\mathrm{UV}_{\text {current }}\right)$ if the animals are slaughtered.
In addition to the leather, an informant described the use of hoof of Euphractus sexcinctus (Linnaeus, 1758) to decorate the residence. Another interviewee reported the use of rennet (stomach) of $K$. rupestris in the preparation of cheese, making the process faster; this trend has already been recorded in other research [78].

The species related to the traditional medicinal use corroborate the list of mammals described by researchers over the years in Brazil [10, 12, 36, 70, 78]. With regard to the magic/religious and veterinary categories, C. thous had one citation in each one of them. For the first purpose, the tail is placed on domestic animals (cattle, goats, and sheep) to prevent the approach of bat species. For the traditional veterinary practice, "lard" (animal fat) is melted and then applied to females of domestic animals, such as cows, goats, and sheep, after the delivery process in order to clean the uterus of these animals.

Thus, utility citations relating to the species reflect their general use value, which may or may not be altered when the analysis of the current use value is performed. It should be noted that the low current use value may be related to several factors, such as a reduction in the use and concealment of information, due to the illegal use of wild animals.

Another factor possibly related to this preference, based on the interviews, is justified by two biases: (1) Perceived abundance of these animals, since, when the informants were asked about the abundance of species, C. thous and G. spixii was described as one of the most found in the region (respectively, 53 and 39 citations referring to high abundance perceived). This data was collected through visual stimulation, using figures (squares) containing different numbers of dots to represent the perceived abundance of the species in the area, seeking to standardize and reduce the subjectivity of the information provided by the interviewees.

(2) Spatial distribution, all the informants $(n=108)$ indicated the different areas where the mentioned species may be found, extending from conserved areas to anthropized areas, since G. spixii is found in several environments distinguishable by the informants, such as open field, closed field, quarries, crops of forage cactus, and near the residences, which reflected its high number of citations and higher general use value and current use value. Some studies conducted in traditional communities also reported the identification of ecological zones by the informants (e.g., $[79,80])$. Such specialties relating to local ecological knowledge facilitate the collection of specimens (animals), making possible the attribution of utility value to the animals.

Some of the cited species are used for more than one purpose. The multiple uses of a species can be discussed from two different points of view. The former is a 
conservationist because the use of a species for different purposes means additional uses or hunting and may result in pressure on this species. The more diversified the attributions to a species are, the higher the chance of it being known/used by the population and the higher probability of it being introduced into the culture by replacing an extinct species [18, 24, 78, 81-83].

The second one concerns the optimization of the use of natural resources by the local community, considering that, due to the peculiar socioeconomic situation of the residents, they attempt to make the most of the available resources, since a large part of these by-products (tails, carapace, bones) would be discarded [18, 24, 78, 83, 84]. Thus, the same species can have its by-products used as food, in traditional medicine, to make some items, etc. Mendonça et al. [85], in a study carried out in the semiarid region of Brazil, reported that it is quite common for local hunters to make the most of the hunted animal parts, resulting in at least two distinct uses for the majority of cinegetic resources, including species considered dangerous to man or to domestic animals.

In the present work, the biomass of the species had no influence on their $\mathrm{UV}_{\text {current }}$, evidenced in the simple linear regression (the relationship between biomass and the $\left.\mathrm{UV}_{\text {current }}\right)$. Although according to the Optimal Foraging Theory, local populations prefer to use animals of higher biomass, obtaining a greater quantity of resources per hunting and/or manufacturing time [40, 46, 48], several studies have reported that as the medium- and largesized species are depleted, typical species with higher availability become the subsequent targets $[40,42,78$, 86-90]. In fact, this is the trend pointed out in ethnobiological studies around the world (e.g., [91-96]). Therefore, small-sized species may be as important for the communities as large-sized species (higher biomass).

Some authors have reported the hunting of small-sized species in other semi-arid areas in Brazil, such as Mendonça et al. [88], who investigated the preference of hunters for species of large, medium, and low body biomass and found that hunters in the semi-arid region have no significant preference for large-sized animals. Therefore, people have developed a peculiar way of dealing with and making the most of available resources, which are often obtained in large quantities, thus making up for the low body weight of species of local importance.

Several cultural and ecological factors are associated with the choice and use of species in the Caatinga [16, $42,87,88$ ], which may justify the variations between the different use values attributed to each species (see Table $3)$. For example, small- $(<1 \mathrm{~kg})$ and medium-sized species $(1-5 \mathrm{~kg})$ such as G. spixii, T. apereoides, $K$. rupestris, Didelphis albiventris Lund, 1840 and Callithrix jacchus (Linnaeus, 1758) (< $1 \mathrm{~kg})$, Dasypus novemcinctus (Linnaeus, 1758), E. sexcinctus, and Sylvilagus brasiliensis
(Linnaeus, 1758) (1-5 kg) had high $\mathrm{UV}_{\text {general }}$ and $\mathrm{UV}_{\text {cur- }}$ rent (Table 3 ) and high reproductive and density rates, and except for Kerodon rupestris (WIED-NEUWIED, 1820), all these species are generalist as for the use of habitat, are widely distributed, and tolerate anthropogenic disturbances (r-strategists) [9, 97-102].

$K$. rupestris despite being a specialist in using habitats (rocky outcrops and mountainous areas), it has a high reproductive rate and gregarious habit $[9,103]$. This species is endemic to the Caatinga, and although it is widely distributed throughout this biome, it is classified as vulnerable on the national list of endangered species, due to the hunting pressure [104].

With regard to D. novemcinctus and E. sexcinctus, according to Marinho et al. [105], the abundance of these species in areas of Caatinga is very relative and although they are hunted in several areas $[12,16,35,42,70,78$, $88,106,107]$ they are widely distributed in the biome. Other medium-sized species $(1-5 \mathrm{~kg})$ such as Conepatus amazonicus (Lichtenstein, 1838) and Tamandua tetradactyla (Linnaeus, 1758), despite having low population densities and low reproductive rates, are easily found in several areas of the Caatinga [9].

Regarding C. thous, it is reported in the literature as a medium-sized animal with the highest number of records in Paraíba, Pernambuco, Ceará, and Alagoas. This species occurs in all habitats, visibly adaptable to anthropized areas, and is found even in green areas of cities [9, 108]. Thus, it is constantly seen, which results in its high perceived abundance, described by the interviewees, and in the consequent association with purposes of use.

With regard to the mesopredator carnivorous (5-10 $\mathrm{kg}$ ) such as tayras (Eira barbara), crab-eating raccoon (Procyon cancrivorus), and all Felidae species and top predators such as Puma concolor (Linnaeus, 1771) (> 15 $\mathrm{kg}$ ), some studies have shown that these species already occur in low population densities and have ecological and behavioral peculiarities which make them more vulnerable to anthropogenic pressures $[9,97,98,105,109]$. The felines recorded in the present study, except for Leopardus pardalis (Linnaeus, 1758), are classified as vulnerable on the national and international lists of endangered species $[104,110]$. The state of $P$. concolor is more critical in the Caatinga than it is in the national classification; in this biome, this species is classified as endangered $[105,111]$.

Another important factor is that although there are many large-sized animals in the Caatinga $[9,105]$, they are strongly affected by hunting and habitat loss because they are $\mathrm{k}$-specialists and have several trophic requirements, low reproductive rate, long lifetime, and are very susceptible to anthropogenic disturbances $[9,97,98,105]$.

All these factors are aggravated by the increased aridity and increase in areas susceptible to desertification 
since $20 \%$ of the Caatinga is undergoing desertification $[106,112]$. This may explain the absence of many other species, evidencing the need for future studies aimed to investigate how wild populations respond to the impacts caused by human activities. It is worth mentioning that, in this ecosystem, most studies on the ecology of species and on factors associated with anthropogenic impacts are still local and incipient $[9,16,35,105]$.

The $\mathrm{UV}_{\text {current }}$ of the cited species ranged from zero to 1.49 and the $\mathrm{UV}_{\text {potential }}$ from 0.02 to 1.57. Most of the animals had UVs (general, potential, and current) lower than 1, but eight species had higher UVs, which reflect their local importance to the community. Thus, a high $\mathrm{UV}_{\text {current }}$ is worrisome in the case of local exploitation; however, a high $U V_{\text {potential }}$ may indicate the lack of species in the region $[90,107]$. It is worth noting that although species of high potential use values are not effectively used, they can become part of the regular uses as the currently used species are extinct $[39,90-93]$. Another relevant consideration is that species with high potential use may be absent in the region, which may explain the recognition and no effective use of potential species $[92,107]$.

Although we have collected no quantitative data on consumption frequency and number of animals slaughtered, as well as no data on species abundance, frequency, and use of habitat, based on information from local residents and other studies on hunting and use of wild animals in the Caatinga [10, 12, 16, 42, 70, 88], the use of wild mammals is widely disseminated in several areas and is the main cause of population reduction and local extinction of several species [35, 42, 101, 109].

Some studies [90, 107, 113-115] have shown that the application of differentiated UV results in more precise diagnoses regarding the cultural importance of the species used. Thereby, aiming at strategies for the conservation of these animals, further studies are needed to evaluate if the local decrease in the population of some species, from the informants' point of view, is directly related to their use and/or to other factors, such as population fluctuation and changes in their habitat, among others. These factors may be associated with the capture/use of the species and are fundamental data for the development of conservation strategies.

Although the UV is a data analysis tool widely used in recent ethnobiological studies, a standard method for collecting and analyzing the data on the uses cited by the interviewees has not yet been established. This divergence in obtaining information may provide a margin for crucial errors in the results obtained by the researchers.

The results presented here show the importance of adopting the $U V_{\text {current }}$ in the analysis of ethnobiological data since this UV explains the effective use of natural resources and is significantly different from the $\mathrm{UV}_{\text {general }}$ of the species, based on the Cluster test and onewayANOVA. No studies had statistically measured this difference, until now, although some authors have pointed out the need to assess the applicability of this index [92, 107, 113-115]. Therefore, the data from this research suggest a new standard for data analysis using the $\mathrm{UV}_{\text {current }}$ as a strategic tool for the conservation of the most important species. The systematization in data organization works as a support for more reliable comparisons between ethnobiological studies. Thereby, the present ethnozoological study, since its data is quantitatively interpreted, needs to be categorized and delimited to provide reliable results on how these people use natural resources.

\section{Conclusions}

In this context, it is expected that other studies, using this differentiated UV method, systematize the calculation according to each citation described by informants, considering that such information may be situational and modifiable according to the area and time where the research will be developed. However, these studies must be able to point out which species possibly require conservation strategies to minimize negative impacts on biodiversity. Such information becomes increasingly necessary not only for the preservation of the Caatinga but also for other ecosystems in which there is a relationship between humans and natural resources for utilitarian purposes.

The understanding of this technique and its consequent standardization proposed in this article can represent a fundamental reference for future ethnozoological studies and may contribute to the development of management plans and sustainable use of the wild fauna by traditional populations that depend on this resource for survival.

\section{Acknowledgements}

The authors would like to thank all the participating locals for their warm reception and for agreeing to participate in the study.

\section{Authors' contributions \\ SSS, HKLS, VMSS, and NSL collected and analyzed the data and wrote the manuscript; LETM and RFPL coordinated the field research and the writing of the manuscript. All authors read and approved the final manuscript. \\ Funding \\ Not applicable. \\ Availability of data and materials \\ The authors do not wish to provide data from their studies, as some databases charge fees and there is no proper Brazilian database.}

\section{Ethics approval and consent to participate}

The aim of this study was explained to each informant, who was then asked to sign a consent form, as required by the National Health Council and the Research Ethics Committee (Resolution 466/12). This research was approved by the Research Ethics Committee of the State University of Paraíba (Protocol No. 45051115.5.0000.5187). The authors interviewed 108 informants, who were informed of the aim of this scientific research and agreed to sign an informed consent form, according to necessary standards, and as described in the methodology through the protocol number. 


\section{Consent for publication}

The participants who signed the consent form were aware that this scientific research could be published in the academic milieu.

\section{Competing interests}

The authors declare that they have no competing interests.

\section{Author details}

${ }^{1}$ Universidade Federal da Paraíba, João Pessoa, Brazil. ${ }^{2}$ UEPB, Campina Grande, Brazil. ${ }^{3}$ PRODEMA, João Pessoa, Brazil. ${ }^{4}$ Campus I, Center of Exact and Natural Sciences, Department of Systematics and Ecology, Laboratory of Ethnobiology and Environmental Sciences, Federal University of Paraíba, João Pessoa, Brazil. ${ }^{5}$ UFRJ, Rio de Janeiro, Brazil. ${ }^{6}$ Biology Department, State University of Paraíba, João Pessoa, Brazil.

\section{Received: 19 August 2018 Accepted: 21 June 2019 Published online: 09 July 2019}

\section{References}

1. Paglia AP, Fonseca GAB, Rylands AB, Herrmann G, Aguiar LMS, Chiarello AG, Leite YLR, Costa LP, Siciliano S, Kierulff MCM, Mendes SL, Tavares VC, Mittermeier RA, Patton JL. Lista Anotada dos Mamíferos do Brasil / Annotated checklist of Brazilian mammals. 2a Edição / 2nd Edition. Occasional Papers in Conservation Biology. 2012, 6, 76 pp.

2. Albuquerque UP, Araújo EL, El-deir ACA, Lima ALA, Souto A, Bezerra BM, Ferraz EMN, Freire EMX, Sampaio EVS, Las-casas FMG, Moura GJB, Pereira GA, Melo JG, Ramos MA, Rodal MJN, Schiel N, Lyra-Neves RM, Alves RRN, Azevedo-Júnior SM, Telino-Júnior WR, Severi W. Caatinga revisited: ecology and conservation of an important seasonal dry forest. Scientific World Journal. 2012:1-18.

3. Mares MA, Wilig MR, Lacher-Jr TE. The Brazilian Caatinga in South American zoogeographic: tropical mammals in a dry region. J Biogeograph. 1985;12:57-69.

4. Mares MA, Wiilig MR, Streilein KE, Lacher-Jr TE. The mammal of northeastern Brazil: a preliminary assessment. Annals Carnegie Museum. 1981;50(4):81-100.

5. Oliveira JA. Diversidade de mamíferos e o estabelecimento de áreas prioritárias para a conservação do bioma Caatinga. In: Silva JMC, Tabarelli M, Fonseca MT, Lins LV. (Orgs.). Biodiversidade da Caatinga: áreas e ações prioritárias para a conservação. Ministério Do Meio Ambiente/Universidade Federal De Pernambuco. 2004, 264-282.

6. Monteiro MAOC, Borges-Nojosa DM, Langguth AR, Sousa MAN, Silva LAM, Leite LMRM, Prado FMV, Veríssimo KCS, Moraes BLC. In: Araújo FS, Rodal MJN, Barbosa MRV. (Eds). Análise das variações da biodiversidade do bioma Caatinga, suporte e estratégias regionais de conservação. Biodiversidade 12. Ministério Do Meio Ambiente. 2005,16-33.

7. Wilson EOA. Situação atual da diversidade biológica. In: Biodiversidade. Rio De Janeiro: Nova Fronteira; 1997.

8. Willig MR. Bat community structure in South America: a tenacious chimera Revista Chilena de Historia Natural. 1986;59:151-68.

9. Feijó JA, Langguth A. Mamíferos de médio e grande porte do Nordeste do Brasil: distribuição e taxonomia, com descrição de novas espécies. Revista Nordestina de Biologia. 2013;22(1):3-225.

10. Melo RS, Silva OC, Souto A, Alves RRN, Schiel N. The role of mammals in local communities living in conservation areas in the Northeast of Brazil: An ethnozoological approach. Tropical Conservation Science. 2014;7(3):423-39.

11. Souza JB, Alves RRN. Hunting and wildlife use in an Atlantic Forest remnant of northeastern Brazil. Trop Conserv Sci. 2014;7(1):145-60.

12. Santos SS, Soares HKL, Soares VMS, Lucena RFP. Conhecimento tradicional e utilização da fauna silvestre em São José da Lagoa Tapada, Paraíba, Brasil. Revista Etnobiología. 2019;17(1):31-48.

13. Barbosa JEA, Aguiar JO, Alves RRN. Medicinal use of animals by hunters in North Easters Brazil. Indian J Tradit Knowl. 2018;17(3):485-93.

14. Léo-Neto NA, Alves RRN. A Natureza Sagrada do Candomblé: Análise da construção mística acerca da natureza em terreiros de Candomblé em Caruaru (PE) e Campina Grande (PB). Interciência. 2010:35:568-74.

15. Mendonça LET, Souto CM, Andrelino LL, Souto WMS, Vieira WLS, Alves RRN. Conflitos entre pessoas e animais silvestres no Semiárido paraibano e suas implicações para conservação. Sitientibus série Ciências Biológicas. 2011:11(2):185-99.

16. Alves RRN, Mendonça LET, Confessor MVA, Vieira WLS, Lopez LCS. Hunting strategies used in the semi-arid region of northeastern Brazil. J Ethnobiol Ethnomed. 2009:5(12):1-56
17. Alves RRN, Oliveira MDGG, Barboza RRD, Lopez LCS. An ethnozoological survey of medicinal animals commercialized in the markets of Campina Grande, NE Brazil. Human Ecology Review. 2010;17:11-7.

18. Alves RRN, Rosa IL, Léo Neto NA, Voeks R. Animals for the gods: magical and religious faunal use and trade in Brazil. Human Ecology. 2012a;40:751-80.

19. Barbosa JAA, Aguiar JO. Conhecimentos e usos da fauna por caçadores no semiárido brasileiro: um estudo de caso no estado da Paraíba, Nordeste do Brasil. Biotemas. 2015;28(2):137-48.

20. Chiarello AG, Aguiar LMS, Cerqueira R., Melo FR, Rodrigues FHG, Silva VMF. Mamíferos. In: Ministério do Meio Ambiente: Livro Vermelho da Fauna Brasileira Ameaçada de Extinção. Brasília 2008. Ministério do Meio Ambiente.

21. Robinson JG, Redford $\mathrm{KH}$. Sustainable harvest of neotropical forest mammals. In: Neotropical Wildlife Use And Conservation (ed.) Robinson, J.G. e Redford, K H. Chicago, II, USA: University Of Chicago Press; 1991. p. 415-29.

22. Willig MR, Mares MA. Mammals from the Caatinga: an updated list and summary of recent research. Revista Brasileira de Biologia. 1989;49(2):361-7.

23. Collar N, Wege DC, Long AJ. Patterns and causes of endangerment in the new world avifauna. Ornithol Monogr. 1997;48:237-60.

24. Alves RRN. Relationships between fauna and people and the role of ethnozoology in animal conservation. Ethnobiology Conserv. 2012;1:1-69.

25. IUCN - International Union for Conservation of Nature. Iucn Red List Of Threatened Species. Version 2019-1. Disponível em: <https://www. iucnredlist.org/> Acesso em: 10 de abril de 2019.

26. Phillips O, Gentry AH. The useful plants of Tambopata, Peru: I. Statistical hypotheses test with new quantitative technique. Econ Bot. 1993;47(1):15-32.

27. Phillips O, Gentry AH. The useful plants of Tambopata, Peru: II. Additional hypothesis testing in quantitative ethnobotany. Economic Botany. 1993a;47(1):33-43

28. Rossato SC, Leitão-Filho HF, Begossi A. Ethnobotany of Caiçaras of the Atlantic Forest Coast (Brazil). Econ Bot. 1999;53:387-95.

29. La Torre-Cuadros MA, Islebe EGA. Traditional ecological knowledge and use of vegetation in southeastern México: a case study from Solferino, Quintana Roo. Biodivers Conserv. 2003;12:2455-76.

30. Lucena RFP, Albuquerque UP, Araújo EL. Does the use-value of woody plants of the Caatinga (northeastern Brazil) explain their local availability? Econ Bot. 2007;61(4):347-61.

31. Lucena RFP, Albuquerque UP, Monteiro JM, Almeida CFCBR, Florentino ATN, Ferraz JSF. Useful plants of the semi-arid northeastern region of Brazil - a look at their conservation and sustainable use. Environ Monit Assess. 2007a;125:281-190.

32. Molares S, Ladio A. Ethnobotanical review of the Mapuche medicinal flora: use patterns on a regional scale. J Ethnopharmacology. 2009;122:251-60.

33. Bezerra DMMSQ, Araujo HFP, Alves RRN. The use of wild birds by rural communities in the semi-arid region of Rio Grande do Norte state, Brazil. Bioremediation, Biodiversity and Bioavailability. 2011, 5 (Special Issue 1): 117-120.

34. Souto WMS, Mourão JS, Barboza RRD, Mendonça LET, Lucena RFP, Confessor MVA, Vieiras WLS, Montenegro PFGP, Lopez LCS, Alves RRN. Medicinal animals used in ethnoveterinary practices of the 'Cariri Paraibano', NE Brazil. J Ethnobiol Ethnomed. 2011;7:30.

35. Alves RRN, Melo MF, Ferreira FS, Trovão DMBM, Dias TLP, Oliveira JV, Lucena RFP, Barboza RRDB. Healing with animals in a semiarid northeastern area of Brazil. Environ Dev Sustain. 2016;18:1733-47.

36. Bonifácio KM, Freire EMX, Schiavetti A. Cultural keystone species of fauna as a method for assessing conservation priorities in a protected area of the Brazilian semiarid. Biota Neotropica. 2016, 16(2).

37. Silva N, Lucena RFP, Lima JRF, Lima GDS, Carvalho TKN, Sousa Júnior $\mathrm{SP}$, Alves CAB. Conhecimento e uso da vegetação nativa da Caatinga em uma comunidade rural da Paraíba, Nordeste do Brasil. Bol Mus Biol Mello Leitão. 2014;34:5-37.

38. Stebbins RA. Fitting in: the researcher as learner and participant. Qual Quant. 1987:21(1):103-8.

39. Lucena RFP, Medeiros PM, Araújo EL, Alves AGC, Albuquerque UP. The ecological apparency hypothesis and the importance of useful plants in rural communities from northeastern Brazil: An assessment based on use value. J Environ Manag. 2012;96:106-15.

40. Melo ERA, Gadelha JR, Silva MND, Silva-Júnior AP, Pontes ARM. Diversity, abundance and the impact of hunting on large mammals in two contrasting forest sites in northern Amazon. Wildl Biol. 2015;21(5). https:// doi.org/10.2981/wlb.00095.

41. Silva-Neto BC, Nascimento ALB, Schiel N, Alves RRN, Souto A, Albuquerque UP. Assessment of the hunting of mammals using local ecological 
knowledge: na example from the Brazilian semiarid region. Enviromen Dev Sustain. 2015. https://doi.org/10.1007/s10668-016-9827-2.

42. Barboza RRD, Lopes SF, Souto WMS, Fernandes-Ferreira H, Alves RRN. The role of game mammals as bushmeat in the Caatinga, northeast Brazil. Ecol Soc. 2016;21(2):2. https://doi.org/10.5751/ES-08358-210202.

43. Van Vliet N, Muhindo J, Nyumu JK, Mushagalusa O, Nasi R. Mammal depletion processes as evidenced from spatially explicit and temporal local ecological knowledge. Trop Conserv Sci. 2018;11:1-16. https://doi.org/10.11 77/1940082918799494.

44. Begossi A. Ecologia humana: um enfoque das relações homem-ambiente. Interciencia. 1993;18(1):121-32.

45. Begossi A. Sepetiba Bay project: an ecological approach to fishing communities. Human Ecology Bulletin, Spring/Summer. 1991;(7): 4-7.

46. Pyke GH. Optimal foraging theory: a critical review. Annual Review of Ecology and Systematics. 1984;15:523-75.

47. Sturtevant WC. Studies in ethnoscience. American Anthropologist. 1964, (3part2: Transcultural Studies in Cognition): 99-131.

48. Alvard M, Alcorn JB, Bodmer RE, Hames R, Hill K, Hudson J, Lyman RL, Puri RK, Smith EA, Stearman AM. Intraspecific prey choice by Amazon hunters. Am Anthropol. 1995;36(5):789-818.

49. Rist J, Rowcliffe M, Cowlishaw G, Milner-Gulland EJ. Evaluating measures of hunting effort in a bushmeat system. Biol Conserv. 2008. https://doi.org/10.1 016/j.biocon.2008.06.005.

50. Parry L, Barlow J, Peres CA. Hunting for sustainability in tropical secondary forests. Conserv Biol. 2009;23(5):1270-80. https://doi.org/1 0.1111/j.1523-1739. 2009a.01224.x.

51. Meyer-Rochow VB. Food taboos: their origins and purposes. J Ethnobiol Ethnomed. 2009. 5:18. https://doi.org/10.1186/1746-4269-5-18.

52. Alves RRN, Souto WMS. Ethnozoology: a brief introduction. Ethnobiol Conserv. 2015;4(1):1-13. https://doi.org/10.15451/ec2015-1-4.1-1-13.

53. CPRM. Serviço Geológico do Brasil (Recife, PE). Projeto cadastro de fontes de abastecimento por água subterrânea. Diagnóstico do município de Solânea, Estado da Paraíba. 2005

54. IBGE - Instituto Brasileiro De Geografia e Estatística. 2014, Disponível em: < http://www.cidades.ibge.gov.br/xtras/perfil.php?lang = \&codmun = 251600\&search $=$ paraibalsolanea $>$. Acesso em 20/03/18.

55. Albuquerque UP, Sousa TA, Soldati GT. O "Retorno" das pesquisas Etnobiológicas para as comunidades. In: Albuquerque UP, Lucena RFP, Cunha LVFC, editors. Métodos e técnicas na pesquisa etnobiológica e etnoecológica. Recife: Nupeea; 2010.

56. Huntington HP. Using traditional ecological knowledge in science: methods and applications. Ecol Appl. 2000;10(5):1270-4

57. Confessor MVA, Mendonça LET, Mourão JS, Alves RRN. Animals to heal animals: ethonoveterinary practices in semi-arid region, northeastern Brazil. J Ethnobiol Ethnomed. 2009;5:37.

58. Mc Bee K, Baker R.J. Dasypus novemcinctus. Mamm Species. 1982, 162: 1-9.

59. Hayssen V. Tamandua tetradactyla (Pilosa: Myrmecophagidae). Mamm Species. 2011;43(1):64-74.

60. Bonvicino CR, Oliveira JA, D'Andrea PS. Guia dos roedores do Brasil, com chaves para gêneros baseadas em caracteres externos. Rio de Janeiro: Centro Pan-Americano de Febre Aftosa - OPAS/ OMS; 2008. p. 12.

61. Topp-Jorgensen E, Nielsen MR, Marshall AR, Pedersen U. Densidades Relativas de Mamíferos em Resposta a Diferentes Níveis de Caça à Caça de Bush nas Montanhas Udzungwa, Tanzânia. Trop Conserv Sci. 2009;2(1):7087. https://doi.org/10.1177/194008290900200108.

62. Altaf M, Javid A, Umair M, labal KJ, Rasheed Z, Abbasi AM. Ethnomedicinal and cultural practices of mammals and birds in the vicinity of river Chenab, Punjab-Pakistan. J Ethnobiol Ethnomed. 2017;13:41. https://doi.org/10.1186/ s13002-017-0168-5.

63. García-Flores A, Lozano-García MA, Ortiz-Villaseñor AL, Monroy-Martinez R. Uso de mamíferos silvestres por habitantes del parque nacional el Tepozteco, Morelos, México. Etnobiología. 2014. 12 (3)

64. Gonzalez JA, Vallejo JR. Vertebrados silvestres usados en la medicina popular del sector centro-occidente de Espana: una revision bibliografica. Etnobiología. 2014;12(1):1-22.

65. Monroy R, Garcia-Flores A. La fauna silvestre com valor de uso en los huertos fruticolas tradicionales de la comunidad indigena de Xoxocotla, Morelos, Mexico. Etnobiología. 2013;11(1):44-52.

66. Valle YG, Naranjo EJ, Caballero J, Martorell C, Ruan-Soto F, Enríquez PL. Cultural significance of wild mammals in mayan and mestizo communities of the Lacandon Rainforest, Chiapas, Mexico. J Ethnobio Ethnomed. 2015:11(36):1-13.

67. IBGE - Instituto Brasileiro de Geografia e Estatística, Síntese de indicadores sociais: uma análise das condições de vida da população brasileira. Coordenação de populações e indicadores sociais, Rio de Janeiro: IBGE, Estudos e pesquisas - Informações demográficas e socioeconômicas, (35) (2015) 134.

68. Silva AAS, Ferreira EC, Santos SS, TKN C, Lucena CM, Nunes GM, VJP MF, RFP L, RFP L. Utilização de plantas na veterinária popular no semiárido da Paraíba, vol. 1. Nordeste do Brasil.: FLOVET - Boletim do Grupo de Pesquisa da Flora, Vegetação e Etnobotânica; 2018. p. 37-60.

69. Machado JS, Lucena CM, Santos SS, Ferreira EC, Nunes GM, RFP L. Conhecimento botânico local sobre cactáceas: um estudo de caso no município de Boqueirão, vol. 1. Paraíba, Nordeste do Brasil: FLOVET- Boletim do Grupo de Pesquisa da Flora, Vegetação e Etnobotânica; 2018. p. 1-21.

70. Lima JRF, Santos SS, Lucena RFP. 2018. Uso de recursos faunísticos em uma comunidade rural do semiárido da Paraíba - Brasil. Etnobiología. 2018;16(3):36-53.

71. Alves RRN, Policarpo IS, RRD B, HFP A. Perception and use of biodiversity in the vicinity of an urban conservation area, North eastern Brazil. Indian J Tradit Knowl. 2017;16:44-50.

72. Lucena RFP, Albuquerque UP, Almeida CFCBR, Florentino ATN, Ferraz JSF. Plantas úteis da região semiárida do Nordeste do Brasil - Um olhar sobre a sua conservação e uso sustentável. Environ Monit Assess. 2005;125:281-90.

73. Pinto MF, Mourão JS, Alves RRN. Animal source foods consumed in two fishing communities on the northeast coast of Brazil. Environ Dev Sustain. 2017:19:679-92.

74. Monterrubio CL, Lara LEC, Pinera EJC, Torres FB. Uso y conservacion de mamiferos silvestres en uma comunidad de las canadas de la Selva Lacandona, Chiapas, Mexico. Etnobiología. 2007;5:99-107.

75. Monroy-Vilchis O, Cabrera L, Suarez P, Zarco-González MM, Rodríguez-Soto C, Urios V. Uso tradicional de vertebrados silvestres en la Sierra Nanchititla, Mexico. Interciencia. 2008;33(4):308-13.

76. Fa JE, Huste J, Burn RW, Broad G. Bushmeat consumption and preference of two ethnic groups in Bioko Island, West Africa. Hum Ecol. 2002;30:397-416.

77. Schenck M, Effa EN, Starkey M, Wilkie D, Abernethy KA, Telfer PT, Godoy R, Treves A. Why people eat bushmeat: Results from two-choice, taste tests in Gabon, Central Africa. Hum Ecol. 2006;34:433-45.

78. Alves RRN, Gonçalves MBR, Vieira WLS. Caça, uso e conservação de vertebrados no semiárido Brasileiro. Trop Conserv Sci. 2012;5(3):394-416.

79. Smith NJH. Utilization of game along Brazil's Transamazon Highway. Acta Amazonica. 1976;6:455-66.

80. Pinto MF, Nascimento JL, Alves RRN, Meireles AJA. Qual a relação entre etnozoologia e território? Revista Ouricuri. 2013;3(2):068-88.

81. Santos-Fita D, Naranjo EJ, Rangel-Salazar JL. Wildlife uses and hunting patterns in rural communities of the Yucatan Peninsula, Mexico. J Ethnobiol Ethnomed. 2012;8(38):1-17

82. Ferreira FS, Fernandes-Ferreira $H$, Léo Neto NA, Brito SV, Alves RRN. The trade of medicinal animals in Brazil: current status and perspectives. Biodivers Conserv. 2013;22(4):839-70.

83. Souto WMS, Barboza RRD, Fernandes-Ferreira H, Magalhães Júnior AJC, Monteiro JM, Abi-chacra EA, Alves RRN. Zootherapeutic uses of wildmeat and associated products in the semiarid region of Brazil: general aspects and challenges for conservation. J Ethnobiol Ethnomed. 2018;14(60):1-16.

84. Alves RRN, Alves HN. The faunal drugstore: animal-based remedies used in traditional medicines in Latin America. J Ethnobiol Ethnomed. 2011;7(1):43.

85. LET M, WLS V, RRN A. Caatinga ethnoherpetology: relationships between herpeto-fauna and people in a semiarid region of northeastern Brazil. Amphibian Reptile Conserv. 2014;8:24-32.

86. Redford $\mathrm{KH}$, Robinson JG. The game of choice: patterns of Indian and colonist hunting in the neotropics. American Anthropologist. 1987; 89(3):650-67.

87. Fa JE, Brown D. Impacts of hunting on mammals in African tropical moist forests: a review and synthesis. Mammal Review. 2009;39(4):231-64.

88. Mendonça LET, Vasconcellos A, Souto CM, Oliveira TPR, Alves RRN. Bushmeat consumption and its implications for wildlife conservation in the semi-arid region of Brazil. Reg Environ Chang. 2015;16:1-9.

89. Soares VMS, Soares HKL, Lucena RFP, Barboza RRD. Conhecimento, uso alimentar e conservação da avifauna cinegética: Estudo de caso no município de Patos, Paraíba. Inteciencia. 2018a;43(7):491-7.

90. Soares VMS, Soares HKL, Santos SS, Lucena RFP. Local knowledge, use, and conservation of wild birds in the semi-arid region of Paraíba state, 
northeastern Brazil. J Ethnobiol Ethnomed. 2018:14-77. https://doi.org/10.11 86/s13002-018-0276-X.

91. Berkes F. 1984. Competition between commercial and sport fishermen: an ecological analysis. Hum Ecol. 1984;12(4):413-29.

92. Begossi A. The use of optimal foraging theory in the understanding strategies: a case from Sepetiba Bay (Rio de Janeiro state, Brazil). Hum Ecol. 1992;20(4):463-75.

93. Castro F, Begossi A. Ecology of fishing on the Grande River (Brazil): Technology and territorial rights. Fisheries Res. 1995;23:361-73.

94. Aswani S. Patterns of marine harvest effort in southwestern New Georgia, Solomon Islands: resource management or optimal foraging? Ocean Coastal Manag. 1998;40:207-35.

95. Bertrand S, Um B, Guevara-Carrasco R, Gerlotto F. Scale-invariant movements of fishermen: the same foraging strategy as natural predators. Ecol Appl. 2007;17(2):331-7.

96. Marchal P, Poos JJ, Quirijins F. Linkage between fishers foraging, market and fish stocks density: examples from some North Sea fisheries. Fisheries Res. 2007;83:33-43.

97. Robinson JG, Redford KH. Intrinsic rate of natural increase in neotropical forest mammals: relationship to phylogeny and diet. Oecologia. 1986a;68:516-20.

98. Robinson JG, Redford KH. Body size, diet, and population density of neotropical forest mammals. Am Nat. 1986;128(5):665-80.

99. Arita HT, Robinson JG, Redford KH. Rarity in neotropical forest mammals and its ecological correlates. Conserv Biol. 1990;4(2):181-92.

100. Parry L, Barlow J, Peres C, et al. Allocation of hunting effort by Amazonian smallholders: implications for conserving wild life in mixed-use landscapes. Biol Conserv. 2009;142(8):1777-86.

101. Endo W, Peres CA, Salas E, Mori S, Sanches-Vega JL, Shepard GH, Pacheco V, Yu DW. Game vertebrate densities in hunted and non-hunted forest sites in Manu National Park, Peru. Biotropica. 2010:42(2):251-61.

102. Amori G, Chiozza F, Patterson BD, Rondinini C, Schipper J, Luiselli L. Species richness and distribution of neotropical rodents, with conservation implications. Mammalia. 2013;77(1):1-19.

103. Roberts M, Maliniak E, Deal M. The reproductive 'biology of the rock cavy, Kerodon rupestris, in captivity: a study of reproductive adaptation in a trophic specialist. Mammalia. 1984;48(2):1-14.

104. MMA - Ministerio do Meio Ambiete/Instituto Chico Mendes de conservação da biodiversidade. Livro Vermelho da fauna brasileira ameaçada de extinção. 2016

105. Marinho Paulo H, Bezerra D, Antongiovanni M, Fonseca CR, Venticinque EM. Mamíferos de médio e grande porte da Caatinga do Rio Grande do Norte, Nordeste do Brasil. Mastozoología Neotropical. 2018;25(2):345-62.

106. Santos JC, Leal IR, Cortez JSA, Fernandes GW, Tabarelli M. Caatinga: the scientific negligence experienced by a dry tropical forest. Trop Conserv Sci. 2011;4(3):276-86.

107. Santos SS, HKL S, VMS S, RFP L. Traditional knowledge and use of mammals in a rural community in the Sertaneja Depression (Paraíba State, Northeast Brazil). Indian J Tradit Knowl. 2019;18(1):94-103.

108. Dias DM, Bocchiglieri A. Trophic and spatio-temporal niche of the crabeating fox, Cerdocyon thous (Linnaeus, 1766) (Carnivora: Canidae), in a remnant of the Caatinga in northeastern Brazil. Mammalia. 2015

109. Peres C. Effects of subsistence hunting on vertebrate community structure in Amazonian forests. Conserv Biol. 1999;14(1):240-53.

110. IUCN - International Union for Conservation of Nature. lucn Red List Of Threatened Species. Version 2019-1. Disponível em: <https://www. iucnredlist.org/search?query=Puma\%20yagouaroundi\%20\&searchType= species>. Acesso em: 01 de Maio de 2019

111. Azevedo FC, Lemos FG, Almeida LB, Campos CB, Beisiegel BM, Paula RC, Crawshaw Junior PG, Ferraz KMPMB, Oliveira TG. Avaliação do risco de extinção da Onça-parda Puma concolor (Linnaeus, 1771) no Brasil. Biodiversidade Brasileira. 2013;3(1):107-21.

112. Albuquerque UP, Cunha LUFC, Lucena RFP, RRN A. Methods and Techniques in Ethnobiology and Ethnoecology. 1st ed. Berlim: Springer; 2014. p. 480.

113. Ribeiro JES, Carvalho TKN, Ribeiro JPO, Guerra NM, Silva N, Pedrosa KM, Alves CAB, Souza-Júnior SP, Souto JS, Nunes AT, Lima JRF, Oliveira RS, Lucena RFP. Ecological apparency hypothesis and availability of useful plants: testing different use values. Ethnobotany Res Appl. 2014;12:415-32.

114. Ribeiro JPO, Carvalho TKN, Ribeiro JES, Sousa RF, Lima JRF, Oliveira RS, Alves CAB, Lucena RFP. Can ecological apparency explain the use of plant species in the semi-arid depression of northeastern Brazil? Acta Botanica Brasilica. 2014, 28(3).
115. Nunes EM, Guerra NM, Arévalo-Marín E, Alves CAB, Nascimento VT, Cruz DD, Ladio AH, Silva SM, Oliveira RS, Lucena RFP. Local botanical knowledge of native food plants in the semiarid region of Brazil. J Ethnobiol Ethnomed. 2018;14:49.

\section{Publisher's Note}

Springer Nature remains neutral with regard to jurisdictional claims in published maps and institutional affiliations.
Ready to submit your research? Choose BMC and benefit from:

- fast, convenient online submission

- thorough peer review by experienced researchers in your field

- rapid publication on acceptance

- support for research data, including large and complex data types

- gold Open Access which fosters wider collaboration and increased citations

- maximum visibility for your research: over $100 \mathrm{M}$ website views per year

At BMC, research is always in progress.

Learn more biomedcentral.com/submissions 